\title{
Collector solar hot water installation angle optimization in severe cold area
}

\author{
Yueren Wang ${ }^{1}$, Chenfei $\mathrm{Bi}^{12}$ \& Wen Lou ${ }^{12 \star}$, Yueren Wang ${ }^{1}$ Chenfei Bi \& Wen \\ Lou $^{1 *}$ \\ ${ }^{1}$ School of Municipal and Environmental Engineering, Shenyang JianZhu University, Shenyang,
Liaoning, China \\ ${ }^{2}$ Collector solar hot water installation angle optimization in severe cold area
}

KEYWORD: TRNSYS simulation; Solar hot water systems; Installation angle.

\begin{abstract}
In this paper, based on TRNSYS simulation software platform, the simulation study was carried out on the sport center solar hot water system in Shenyang city . The results include different orientations and different installation angle in the one orientation of solar collectors absorb heat, the collector efficiency and other data. Analyzing the result we can conclude the best orientation and best installation angle of each orientation for collector. To optimize the forced direct hot water circulation system provides a basis.
\end{abstract}

\section{INSTRUCTION}

Solar energy is an inexhaustible renewable energy. It not only free to use, and without transportation. Currently, solar hot water system is the most mature and the economy has competitive green energy technologies in the field of solar energy utilization ${ }^{[1]}$. One of the core components of solar hot water system is the solar collector. It is the collector part in the solar hot water system and the installation angle is very important for maximize system's function. As the solar azimuth, solar altitude angle and atmospheric quality of solar radiation impact that reaches the surface of solar collectors will continue to change over time. Therefore, solar radiation will be received is also in change by the different inclinations of solar collectors, so there will be a collector inclination that the amount of solar radiation at the surface of the inclined collector receives maximum energy. In this case, we need to research and analysis annual amount of solar radiation received with collector surfaces of different inclination.

The best angle for collectors have been researched by many scholars, summed up some of the specific areas to adapt to the law. For example, in the US, the collector optimal installation angle is location latitude plus $20^{\circ[2]}$. While in China is generally considered the best collector installation angle is the local latitude. But for China's use of uniform guidelines provide optimal collector tilt somewhat unreasonable, because China's vast territory and the climate of each region varies. Our solar radiation received resource area is divided into four resource area by the quantity of the solar radiation ${ }^{[3]}$.

In this paper, the content is selected Shenyang as a representative of the city for III region. Using TRNSYS simulation software to simulate different installation angle and at different orientations installation of solar hot water systems. Compared the gain solar heat all year, to give a recommended value collector installation angle of the solar hot water system in this region.

\section{PROJECT PROFILE}

Shenyang geographical coordinates is that latitude $41^{\circ} 44^{\prime}$, longitude $123^{\circ} 27^{\prime}$, altitude $44.7 \mathrm{~m}$. The annual average temperature $7.8^{\circ} \mathrm{C}$, the inclined surface according to the amount of the monthly average daily global solar radiation $15.587 \mathrm{MJ} /\left(\mathrm{m}^{2} \cdot \mathrm{d}\right)$, the average number of hours of sunshine $7.706 h^{[4]}$.

This paper simulations the hot water system for sport center in Shenyang. There are three floors in the building, construction area is $5700 \mathrm{~m}^{2}$. Hot water system is composed of collector solar 
energy systems and hot water supply system. System's design principle is similar with conventional domestic hot water supply system. Solar hot water systems include collectors, heat storage tanks, pumps, temperature controller. The thermal storage medium is water. The flow chart of the system is shown in Figure 1.

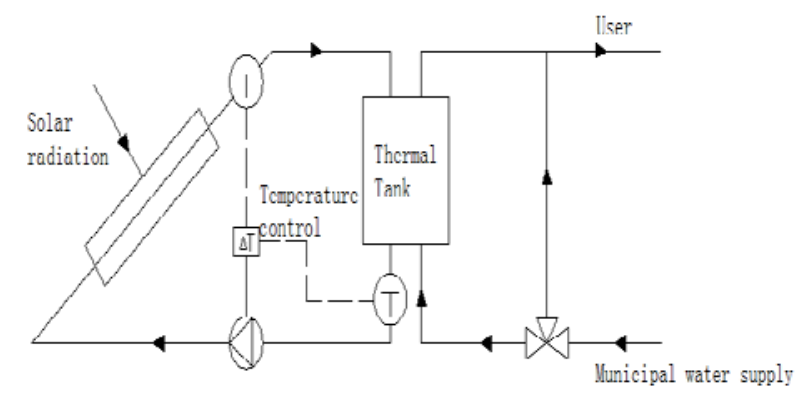

Fig.1 Solar heat water system

\subsection{Solar water heating system's hot water consumption}

In the sports center sets washbasin used every day 250 times, shower 100 times a day. According to the specification shows, sports center washbasins maximum daily water consumption $15 \sim 25 \mathrm{~L}$, communal shower with hot water daily dose for one $50 \sim 80 \mathrm{~L}^{[5]}$. In this case water consumption are selected specification maximum value. Draw design daily water consumption by over conditions for $14250 \mathrm{~L} / \mathrm{d}$.

\subsection{Solar collectors}

The total area of solar collectors of this system is by average water consumption and water temperature. Calculated by Equation 1:

$$
A_{c}=\frac{Q c \rho_{r} f\left(t_{\text {end }}-t_{l}\right)}{J_{T} \eta_{c d}\left(1-\eta_{L}\right)}
$$

Where, $\mathrm{A}_{\mathrm{c}}=$ the total area of the collector; $\mathrm{Q}=$ the average daily water consumption; $\mathrm{c}=$ water specific heat capacity; $\rho_{\mathrm{r}}=$ the density of hot water; $\mathrm{f}=\operatorname{solar}$ fraction $(20 \%-40 \%) ; \mathrm{t}_{\text {end }}=$ design temperature of heat storage tank; $t_{l}=$ the initial temperature of the water; $\mathrm{J}_{\mathrm{T}}=$ average daily solar radiation of collector surface; $\eta_{c d}=$ based on the total collector area collector efficiency; $\eta_{\mathrm{L}}=$ piping and heat accumulator heat loss rate $\left(0.4 \mathrm{~W} / \mathrm{m}^{2}\right)$. The system the total collector area calculate is $500 \mathrm{~m}^{2}$ 。

\subsection{Heat storage tank}

The volume of heat storage tank can be determined by the solar collector area for solar heating system. For small-scale solar water heating systems heat storage tank volume range of 40-100 (L / $\mathrm{m}^{2}$ ), in this case the volume of tank is $20 \mathrm{~m}^{3}$. In the tank because of the water temperature leads to water density different, storage tank will achieve varying degrees of temperature stratification, which makes heat storage tank the upper temperature is high and lower temperature in low ${ }^{[6-10]}$. To maintain a fine temperature stratification in the heat storage tank is good for increase the collector absorption heat, so choose a layered storage tank model in the simulation.

\subsection{The strategy of system control}

In the solar hot water systems, collectors collect solar radiation to heat water in the circulating loop to provide $60^{\circ} \mathrm{C}$ hot water for the sports center. When the temperature of water is too high we can accommodate it through the three-way valve supplying the water to the user after mixing. Temperature controller is to control the collector side of the circulating pump on and off. When the pump is stopped, the collector outlet temperature difference than the temperature of storage tank at 
$10^{\circ} \mathrm{C}$ circulating pump to work, water in the collector and storage tank heat exchange; when the temperature is less than $2^{\circ} \mathrm{C}$ temperature controller circulation pump stop working.

\section{SIMULATION SYSTEM}

\subsection{The theory analysis of collector surface receives solar radiation}

The inclined surface solar irradiance I $\Theta$ consists of three parts: the direct radiation ID $\Theta$, diffuse radiation Id $\Theta$ and ground reflection IR $\Theta$ namely:

$$
\mathrm{I}_{\Theta}=\mathrm{I}_{\mathrm{D} \Theta}+\mathrm{I}_{\mathrm{d} \Theta}+\mathrm{I}_{\mathrm{R} \Theta}\left(\mathrm{W} / \mathrm{m}^{2}\right)
$$

(1)Direct solar radiation

The direction of the solar radiation is absorbed by the Earth's surface and did not change. The direct solar radiation of any plane is impacted by the the installation angle of plane.

(2)Diffuse radiation on an inclined plane

When the light of the sun through the atmosphere, due to the small amount of mist and little dust, so that light is refracted and scattered in all directions. Diffuse radiation is generally considered that is isotropic, in other word diffuse solar radiation is distribution of hemisphere sky. The inclined plane diffuse radiation intensity calculated by the following formula:

$$
I_{d \theta}=D_{d H}(1+\cos S) / 2
$$

Where IdH = horizontal plane diffuse radiation intensity; $\mathrm{S}=$ Slope of angle

(3)The amount of reflected radiation on the ground

The solar radiation on the ground that is isotropic in all orientation, the reflected radiation on the ground by the following formula:

$$
\mathrm{I}_{\mathrm{R} \Theta}=\rho_{G} \quad\left(\mathrm{I}_{\mathrm{DH}}+\mathrm{I}_{\mathrm{dH}}\right)(1-\mathrm{cos}) / 2
$$

Where IDH $=$ The intensity of horizontal surface beam radiation $(\mathrm{W} / \mathrm{m} 2) ;{ }_{G}$ - The reflectance of ground

\subsection{TRNSYS software}

Using TRNSYS software to build system model, shown in Figure 2. The main components in the simulation systems include: meteorological parameter reading means (Type109-TMY2), solar collectors (Type1b), heat storage tank (Type4c), pumps (Type3b), an integrator (Type24), operation results print (Type25c), online output device (Type65c), temperature difference controller (Type2b).

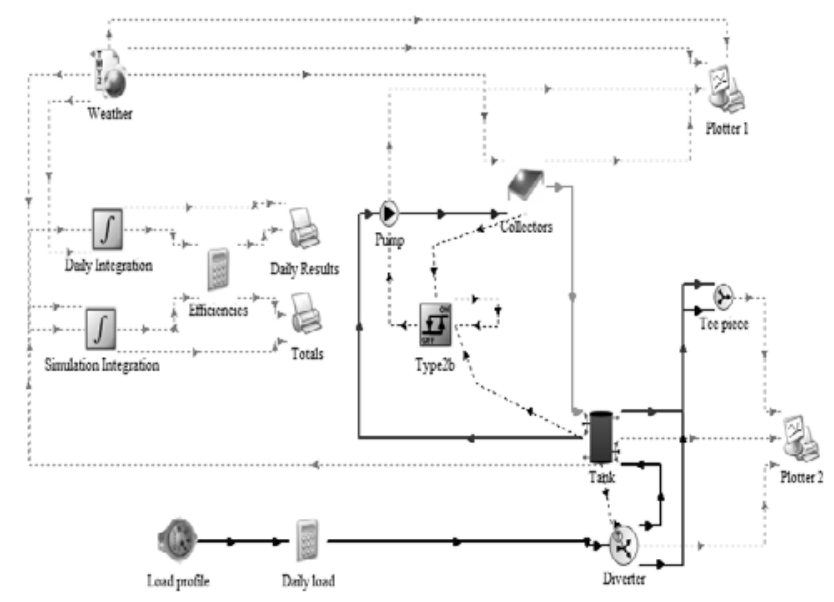

Fig.2 TRNSYS simulation platform 


\subsection{The parameters of Simulation set}

(1) Collector

The collector area and the number of pieces: $2 \mathrm{~m}^{2} /$ sheet, there are 250 in parallel. Through calculate a total collector area is $500 \mathrm{~m}^{2}$, the efficiency curve intercept of 0.8 .

(2) Heat storage tank

Water tank capacity: $20 \mathrm{~m}^{3}$, heat loss coefficient: $0.4 \mathrm{~W} /\left(\mathrm{m}^{2} \cdot \mathrm{K}\right)$, there are two inlet water pipe and two outlet water pipe in the stratified tank.

(3) Circulating pump in collector

Pump flow rate : $4700 \mathrm{~kg} / \mathrm{h}$, delivery head $9 \mathrm{~m}$.

(4) The temperature difference controller

Using on/off control, the high temperature $\mathrm{T}_{\mathrm{h}}$ (collector outlet fluid temperature) and low temperature $\mathrm{T}_{\mathrm{i}}$ (cryogenic storage tank outlet temperature) control pump start or stop.

\section{SIMULATION RESULTS}

Collection efficiency: under working conditions, within the provisions of time the collector collects the amount of solar radiation heat division in the same time solar radiation heat. President of the International Solar Energy Society Mills $D^{[11]}$ proposed solar hot water system design's aim is not to achieve the highest efficiency, but should pursue a minimum of supplementary heat. Therefore, we should pay more attention to collectors absorb heat.

Using TRNSYS model platform shown in Figure 2 has established model to run the simulation of the system throughout the year. We analysis the result and compare the collector absorb heat and solar collector efficiency. The process of simulation the orientation of collector is divided into East, West, South, three directions. In the same azimuth, the inclination angle of the collector is divided into $15^{\circ} 、 30^{\circ} 、 40^{\circ} 、 45^{\circ} 、 60^{\circ} 、 75^{\circ} 、 80^{\circ} 、 90^{\circ}$.

\subsection{Analysis orientation is the south simulation results}

Table1 Collector's orientation is the South different collector installation angle impact on full-year collect

\begin{tabular}{cccc}
\multicolumn{4}{c}{ heat effect } \\
\hline Angle & $\begin{array}{c}\text { Annual radiation } \\
\text { quantity (KJ) }\end{array}$ & $\begin{array}{c}\text { Collector } \\
\text { absorption } \\
\text { heat (KJ) }\end{array}$ & $\begin{array}{c}\text { Collection } \\
\text { efficiency }\end{array}$ \\
\hline $0^{\circ}$ & 2312480254.00 & 918444786.1 & $39.72 \%$ \\
$15^{\circ}$ & 2598380571.00 & 1014639807 & $39.05 \%$ \\
$30^{\circ}$ & 2753893332.50 & 1047945875 & $38.05 \%$ \\
$40^{\circ}$ & 2779464140.00 & 1048910513 & $37.74 \%$ \\
$45^{\circ}$ & 2768677872.00 & 1049477150 & $37.91 \%$ \\
$60^{\circ}$ & 2642635893.00 & 1036427439 & $39.22 \%$ \\
$70^{\circ}$ & 2484575116.50 & 1026499120 & $41.31 \%$ \\
$80^{\circ}$ & 2273206922.50 & 1015635139 & $44.68 \%$ \\
$90^{\circ}$ & 2016169004.00 & 989661659 & $49.09 \%$ \\
\hline
\end{tabular}

From Table 1, when the solar collector facing south, the heat absorbed by the collector trend is that after increase then decreases, but the collection efficiency of the collector trend after decreases and then increases. When the collector installation angle is $40^{\circ}$ the heat is absorbed by collectors is the biggest. When the installation angle of collector is increasing but the collector's effective collector area become less, so the collector absorption heat becoming less. Although in this case collector's collection efficiency better than other case, we will choose the collector absorption heat better case. 


\subsection{Analysis orientation is the west simulation results}

Table2 Collector's orientation is the west different collector installation angle impact on full-year collect heat effect

\begin{tabular}{cccc}
\hline Angle & $\begin{array}{c}\text { Annual radiation } \\
\text { quantity (KJ) }\end{array}$ & $\begin{array}{c}\text { Collector } \\
\text { absorption heat } \\
(\mathrm{KJ})\end{array}$ & Collection efficiency \\
\hline $0^{\circ}$ & 2312480254.00 & 918444786.1 & $39.72 \%$ \\
$15^{\circ}$ & 2274247466.00 & 939039993.5 & $41.29 \%$ \\
$30^{\circ}$ & 2174810663.00 & 947792025.6 & $43.58 \%$ \\
$40^{\circ}$ & 2083627548.00 & 940797372.7 & $45.15 \%$ \\
$45^{\circ}$ & 2031097568.00 & 936750296.1 & $46.12 \%$ \\
$60^{\circ}$ & 1848612979.50 & 904137928.4 & $48.91 \%$ \\
$70^{\circ}$ & 1708409581.50 & 876277250.8 & $51.29 \%$ \\
$80^{\circ}$ & 1556582677.50 & 839697717.4 & $53.94 \%$ \\
$90^{\circ}$ & 1396807282.50 & 786700919.1 & $56.32 \%$ \\
\hline
\end{tabular}

From Table 2, when the solar collector facing west, collection efficiency with the installation angle increases, the collector absorption heat after increase then decreases with the installation of angle increasing change. We can learn from table 2 that when the installation angle is $30^{\circ}$ the collector absorption heat is best.

\subsection{Analysis orientation is the east simulation results}

Table3 Collector's orientation is the east different collector installation angle impact on full-year collect heat

\begin{tabular}{cccc} 
Angle & $\begin{array}{c}\text { Annual radiation } \\
\text { quantity (KJ) }\end{array}$ & $\begin{array}{c}\text { Collector } \\
\text { absorption heat } \\
(\mathrm{KJ})\end{array}$ & Collection efficiency \\
\hline $0^{\circ}$ & 2312480254.00 & 918444786.1 & $39.72 \%$ \\
$15^{\circ}$ & 2265376000.50 & 912879351.8 & $40.30 \%$ \\
$30^{\circ}$ & 2161919058.00 & 898320436.3 & $41.55 \%$ \\
$40^{\circ}$ & 2068115829.00 & 878234535.1 & $42.47 \%$ \\
$45^{\circ}$ & 2014308971.00 & 866845146.8 & $43.03 \%$ \\
$60^{\circ}$ & 1828242788.00 & 825799255.2 & $45.17 \%$ \\
$70^{\circ}$ & 1686199136.50 & 790001976 & $46.85 \%$ \\
$80^{\circ}$ & 1534194405.50 & 739626477.2 & $48.21 \%$ \\
$90^{\circ}$ & 1375042925.00 & 670118616.6 & $48.73 \%$ \\
\hline
\end{tabular}

From Table3, when the solar collector facing east, collection efficiency with the installation angle increases, the collector absorption heat decrease with the installation of angle increasing change. When the installation of angle is $0^{\circ}$, the collector absorption heat is best.

\section{CONCLUSION}

(1)Through simulation results, we can know Shenyang best orientation for solar collectors is the south, as in the South solar collector to absorb heat is higher than the other orientation in the same case. What is more in the south the best angle of installation s between $40^{\circ}$ and $45^{\circ}$.

(2) When the solar collector facing to the west, this paper recommend angle of installation is $30^{\circ}$.In this condition we will get more solar energy.

(3)when the solar collector facing to the east, this simulation recommend angle of installation is $30^{\circ}$. But considering that in the severe winter there will be snow on the collector's area. So solar collector should be maintain a certain inclination angle. So we conclude that when the solar collector facing to east, an angle of installation is recommended between $0^{\circ}$ and $15^{\circ}$.These results can be use for the actual project. 


\section{REFERENCES}

[1] Jiang yunfeng, Liu zhongping, Du yichang. 2004. Investigate residential solar hot water supply.Journal of Shijiazhuang railway station rent Vocational and Technical College .Vol.2 No.2:62 - 65.

[2] 2009. China Academy of Building Research solar heating engineering specifications (GB504952009) [M] Beijing China Building Industry Press.

[3] 2006 .Solar Hot Water Systems Selection and Installation Beijing: China Planning Press.

[4] 2003.Building water supply and drainage design specifications Beijing: China Planning Press.

[5] Yu Guoqing, Tang Jinhua, Zou Zhijun.2007. Research on storage tank temperature stratification in solar hot water system building science. Vol.23, No.4: 71 - 73.

[6] J.van Berkel, C.C.M.Rindt, A.A.van Steenhoven.2002 Thermocline Dynamics in a Thermally Stratified Store. International Journal of Heat and Mass Transfer.(45): 343 356.

[7] Marc A.Rosen.2001.The Energy of Stratified Thermal Energy Storages. Solar Energy 71(3): $173 \sim 185$.

[8] Y.M.Han, R.Z.Wang.2008. Thermal Stratification within the Water Tank. Renewable and Sustainable Energy Reviews71 (3): 1 13.

[9] V.Badescu, M.Dan Staicovici.2006.Model of the Active Solar Heating System. Energy and Buildings 38(2): 129 141.

[10] Mills D,Morrison G L. 2003. Optimisation of minimum backup solar water heating system [J].Solar Energy 74(6):505—511. 